\title{
Unravelling Incoherence Norms of Indonesia's Energy Security Regulations
}

\author{
Indah Cahyani* \\ Administrative Law Department \\ Faculty of Law, Universitas Trunojoyo Madura \\ Bangkalan, Indonesia \\ indah.cahyani@trunojoyo.ac.id
}

\author{
Ekawestri Prajwalita Widiati \\ Constitutional Law Department \\ Faculty of Law, Universitas Airlangga \\ Surabaya, Indonesia \\ prajwalita.widiati@fh.unair.ac.id
}

\begin{abstract}
As a country with huge natural resources potential, Indonesian government enacts series of regulations concerning energy security covering policy on oil and gas. The main problem of Indonesia's energy security policy is disharmony and incoherence among sets of provisions at primary legislations and secondary legislations. To analyze the legal problems, this article employs statute approach and conceptual approach. This normative legal research aims to measure the validity of norms and to confirm whether the set of regulations is viable as the foundation for furthering national energy policy. This article concludes that inconsistence and ambiguous norms results in conflict of authority between managing institutions of oil and gas. The Executive power, therefore, is urged to simplify bureaucracy of national energy security; consolidate series of regulation to a more relevant and repeal the
\end{abstract}

Keywords: energy security, energy policy, energy regulation, oil and gas policy, oil and gas regulation, natural resources

\section{INTRODUCTION}

Effective legislation will solve legislative problems while sloppy draft will create more complexity. Indonesian oil and gas energy is regulated in the Law Number 22 Year 2001 concerning Oil and Gas that is replacing Law Number 8 Year 1971 concerning Oil and Gas Mining Company (PERTAMINA). The 2001 Law regarding Oil and Gas, in fact, brought to the condition where the state lost an exclusive rights of oil and gas authority management by opening "free competition" and removes prevailing authority of state control over oil and gas in Indonesia.

Furthermore, the Constitutional Court through the Constitutional Court Decree Number 36/PUU-X/2012 cancelled several provisions in the Law Number 22/2001 including nullify the function of the government's oil and gas implementing agency (BP Migas). The Constitutional Court also ordered the government to return Indonesia's oil and gas operations from BP Migas to the Ministry of Energy.

The organization management of oil and gas sector seems perplexing. On 2012, Indonesian government then issued Presidential Regulation Number 95 regarding the Changing of the Implementation of Upstream Oil and Gas Duties and Functions Business Activities to implement the Constitutional Court Verdict. However, a year later the President issued another Presidential Regulation Number 9 of 2013 concerning Management of Upstream Oil and Gas Business Activities that opposes the above verdict by re- enacting the operation of new Indonesian oil and gas implementing agency the same idea and same procedure with BP Migas but different name that is titled SKK Migas.

Indonesia's long chain on bureaucracy in the oil and gas business does not end there because it intersects with the regime of energy security matter as regulated in the Law Number 30 Year 2007. The 2007 law concerning national energy security mandates the establishment of the National Energy Council (DEN) which is designated as the agency responsible for the National Energy Policy Planning. As delegated by the Law concerning national energy security of 2007, the Indonesian energy planning including oil and gas, is further elaborated in Regulation of President No. 22 of 2017 concerning the National Energy General Plan (RUEN).

The National Energy Policy according to the Law is settled as the responsibility of DEN. The council works under the authority of the President. Factually, the organizational authority is profligate especially when there is a ministry of energy and resources. Thus, it seems that the government measures on energy security becomes more ambiguous by handing the authority over institutions outside the ministry.

TABLE I. FOSSIL ENERGY LIMITATION (RUEN)

\begin{tabular}{|l|l|r|r|r|r|}
\hline No. & $\begin{array}{c}\text { Type of } \\
\text { energy }\end{array}$ & Resources & Stockpile & Prediction & Time* \\
\hline 1. & Crude oil & $\begin{array}{r}151 \text { billion } \\
\text { barrels }\end{array}$ & $\begin{array}{r}3.6 \text { billion } \\
\text { barrels }\end{array}$ & $\begin{array}{r}288 \text { million } \\
\text { barrels }\end{array}$ & $\begin{array}{r}12 \\
\text { years }\end{array}$ \\
\hline 2. & $\begin{array}{l}\text { Natural } \\
\text { gas }\end{array}$ & $487 \mathrm{TCF}$ & $98.0 \mathrm{TCF}$ & $3.0 \mathrm{TSCF}$ & $\begin{array}{r}33 \\
\text { years }\end{array}$ \\
\hline 3. & Coal & $\begin{array}{r}120.5 \\
\text { billion tons }\end{array}$ & $\begin{array}{r}32.4 \text { billion } \\
\text { barrels }\end{array}$ & $\begin{array}{r}393 \text { million } \\
\text { tons }\end{array}$ & $\begin{array}{r}82 \\
\text { years }\end{array}$ \\
\hline 4. & CBM & $453 \mathrm{TSCF}$ & - & - & - \\
\hline 5. & $\begin{array}{l}\text { Shale } \\
\text { Gas }\end{array}$ & $574 \mathrm{TSCF}$ & - & - \\
\hline
\end{tabular}

Currently Indonesia's oil and gas energy needs are increasing every year while production capabilities are declining. Data for 2013-2020 is based on trends and estimates of the BP Statistical Review, it is estimated that Indonesia in 2020 will have to import about 1.6-1.7 barrels of oil and gas per day. This number will be even greater because domestic production is only 650 thousand BPOD, still to be shared with the foreign contractors portion producing in the Indonesian oil and gas fields. 
Since 2004, Indonesia has become a net oil importer as the production continues to decline. This is due to the increasing need for oil. The limited number of oil refinery facilities which have not been significantly increased since the construction of the Balongan refinery in 1994 made the situation worse, so that the import of fuel oil continue to elevate.

The modeling of petroleum energy supply in the primary energy mix in 2025 was $24.7 \%$ (98.7 MTOE) and in 2050 it was $19.5 \%$ (197.7 MTOE). The portion of the petroleum energy mix is indeed shrinking in percentage but in volume it continues to increase, namely 98.7 MTOE in 2025 and 197.7 MTOE in 2050 (RUEN Number 22 of 2017), that condition should be a separate concern by spurring structuring Indonesia's energy sector is even more worrying.

As a country rich in natural resources, Indonesia needs to organize the arrangement of oil and gas implementation at its best considering the fact that source of oil and gas is unrenewable energy. The principles of Good Administration need to be consequently implemented so that the fossil energy resources can be managed for the prosperity of the nations [5]. The fact that there are number of implementing agencies that is independent, permanent and has authority over national policy and regulation also has supervision authority alongside ministry has created huge overlapping and inefficiency.

The most important mandate at Policy of National Energy is to implement a new energy management paradigm that fossil energy is no longer used as an export commodity and foreign exchange earner but rather as capital of a national development. During at that time, oil and other energy resources are preferred as foreign exchangeproducing commodities. Therefore, a more comprehensive policy is needed so that every barrel of oil and every ton of other energy that comes out of can provide maximum benefits to drive the national economy.

\section{RESULT AND DISCUSSION}

\section{A. The Urge of Coherent Provision}

In recent time, Indonesia's foreign exchange earnings are still very dependent on revenues from oil and gas exports. Unfortunately, the oil and gas sector is not well regulated and there are many gaps in ensuring energy security. State foreign exchange reserves that rely on hot money that are not actually owned by the state and are stored in the central bank are prone to being rushed out of the country and causing bankruptcy as in the 1998 economic crisis [7].

The loss of state control over oil and gas makes the state increasingly lose its sources of income from the oil and gas sector, these are two logics that are out of sync between the needs and the reality of oil and gas regulations. control of national oil and gas by Pertamina only controls $12.2 \%$ of 275 oil and gas mining areas. Pertamina's total oil and gas management also only reaches less than $20 \%$.

There is claim that Indonesia's oil and gas conditions are slowing down and declining according to production charts in Indonesia. However, Supermajor the world oil and natural gas industry which has a great influence in the global economic such as; Exxon Mobil, Royal Dutch Shell, British Petroleum (BP), Chevron Corp, Conoco Phillips and Total are still active in Indonesia, with Chevron as the largest oil company in Indonesia and Total as the largest gas company in Indonesia [1]. The existence of Big IOC (International Oil Company) in Indonesia raises the question of whether the graph has indeed decreased or is a tug of interest to lead Indonesia to liberalization by displacing Pertamina and even leading to the privatization of Pertamina so that the state is completely prevented from being present to manage its own wealth [1].

Jaap Hage in his article titled The Method of a Truly Normative Legal Science, describes the theory of coherence by describing the elements of the correlation into three elements: comprehensive, consistent, and support each other [2]. Comprehensive is that a statement should without explicit mention is reflected in its comprehensiveness in the whole legal document whether the norm is in a contract or in a trial file, or in a series of laws [4]. A measure of whether there is a deviation or not is the existence of coherence. In legal practice, for example, is the prosecutor's indictment coherent with the provisions on which the indictment is based, is the plaintiff's claim coherent with statutory regulations, or is a contract coherent with the provisions of the agreement or the principles of the agreement [2].

Consistent in the second element of coherence theory is that a statement does not clash with another statement or a statement does not contain meaning that can make other statements erased or meaningless. The objection that the derived ought is only a legal ought and not a full-blown 'real' ought. To address this objection it was necessary to go into some detail concerning the nature of the 'ought' [2]. The third element of coherence theory is one statement sustaining another statement, one statement reinforcing the other statement (support each other). The third element support each other is the result of the application of the previous element, namely consistency and comprehensiveness so that it displays solid arguments or statements.

Law 12 of 2011 concerning Regulations Formation has provided recommendations related to the principles of drafting legislation including:

a) clarity of purpose;

b) appropriate regulatory authority;

c) conformity between types, hierarchy, and content;

d) can be implemented;

e) usefulness;

f) clarity; and

g) openness

Indonesian Oil and Gas Planning in Law 30 /2007 concerning Energy. National Energy Policy, Government Regulation Number. 79 of 2014 concerning the National Energy Policy [8]. Furthermore, it is elaborated in RI Presidential Regulation No. 22 of 2017 concerning the National Energy General Plan [9]. Legislative reason behind series of Indonesian oil and gas energy do not meet the principle of workability, usefulness and usefulness.

\section{B. The Foundation Of National Energy Security Policy}

The chaotic policies in the oil and gas sector cannot be separated from the problem of overlapping regulations. The over-regulated conditions in Indonesia has made harmonization and synchronization of laws and regulations almost impossible [10]. The size of jurisdiction, government organization, and the layer of government in Indonesia 
affects the complexity of the legislative system [6]. Article 7 of the Law Number 12 Year 2011 concerning Legislative Drafting, determines type and name of legislation in hierarchical order from the highest namely The 1945 Constitution of The Republic of Indonesia; People Consultative Assembly Decree; Laws and Lieu of Law; Government Regulation; Presidential Regulation; Provincial Regulation; City/Municipal Regulation.

Furthermore Article 8 of Law No.12 of 2011 legitimizes other forms of delegation regulations outside of the 7 types of hierarchy listed in Article 7 which covering regulations stipulated by the numbers of state organs namely; People's Consultative Assembly, the People's Representative Council, the Regional Representative Council, the Supreme Court, the Constitutional Court, Financial Audit Board, Judicial Commission, Bank Indonesia, Ministers, agencies, institutions, or commissions at the same level as established by law or the government at the behest of law, the Provincial People's Representative Council, the Governor, the Regency/City Regional People's Representative Council, Regent / Mayor, Village Head or equivalent.

As a result, regulatory complexity both hierarchically and substantively is unavoidable. The Central Government interests in the field of oil and gas energy maintain national energy stability and security so that the country does not fall into a state of energy crisis. The International Energy Agency (IEA), the international organization of oil and gas importing countries, like other countries in the world, requires minimal energy security for its member countries. The IEA requires national energy security as a minimum standard, namely the safety standard of the availability of energy supply reserves to the availability of supplies for the next 90 days [3].

The complexity in set of regulation on energy security policy is cut from the same cloth as the general challenge on the Indonesian legislative system needs serious attention from the government. Indah Cahyani in her dissertation entitled The Principle of Openness in Upstream Oil and Gas Management in Indonesia, explained the practice of making the Minister of Energy and Mineral Resources Regulation of the Republic of Indonesia No. 42 of 2017 which is enacted and then repealed in no more than two weeks to the new one No. 48 of 2017 [5]. The 42 of 2017 Ministerial regulation concerning Supervision of Operations in Business Activities in the Energy and Mineral Resources Sector was stipulated on 14 July 2017. While the No. 48 of 2017 concerning Supervision of Operations in the Energy and Mineral Resources Sector dated on 3 August 2017.

Firstly, The 42/2007 ESDM ministerial regulation and The 48/2007 has the same regulatory content in Article 2, namely the scope of the regulation covering changes in ownership, direct control, and management of the company which includes the transfer of interest participation and/or transfer of shares as well as changes in directors and/or commissioners and procurement mechanisms. Biodiesel (Biofuels) type of biodiesel. The substance of the ministerial regulation does not cover the material of supervision. Referring to the word "supervision" in the ministerial regulation, is the supervisory organ, what to supervised, deviations from what should be the object of supervision, and the gradation arrangement of sanctions from mild to heavy sanctions.
The contents of the ministerial regulation indicates changes in ownership, management of the company which includes transfer of Interest Participation and/or transfer of shares, changes in directors and/or commissioners and the mechanism for procuring biofuel (biofuel) types of biodiesel. The Ministerial Regulation regulates the material imposition of obligations but is not equipped with a mechanism for sanctions if the obligations are not carried out properly.

Secondly, in Article 31 paragraph (3) the closing provisions of The 48/2007 ministerial regulation states that it is intended to replace the effectiveness of The 42/2007 ESDM ministerial regulation. If the replacement of this regulation is desired, with the substance of the regulation as meant, the ministerial regulation should be entitled "Regulation of the Minister of Energy and Mineral Resources No. 48 of 2017 concerning the Amendment to the Regulation of the Minister of Energy and Mineral Resources No. 42 of 2017 concerning Supervision of Operations in Business Activities in the Energy and Mineral Resources Sector"

Thirdly, if it is intended to change the regulation, at least there is a change in the substance of the regulation which shows sufficient reason for the need to change the candy regulation, but between the 42 and 48 regulation there is no different regulatory substance. Clearly the whole substance is the same, namely about regulating changes ownership, management of the company which includes the transfer of Interest Participation and/or transfer of shares, changes in the board of directors and/or commissioners of the Upstream Oil and Gas Cooperation Contract Contractor, Business Entities holding downstream business licenses, Business Entities holding Business Permits for Power Generation Business Permits (IUPTL), Corporate Businesses holding mineral and coal mining business permits, business entities holding geothermal permits and the mechanism for procuring biofuel as types of biodiesel. Fourthly, between the ministerial regulation No.42 of 2017 and No.48 of 2017 was only a difference of two weeks with almost the same title and the same substance.

To date, the issue of subsidized fuel oil has not been resolved properly and completely. Predictably, the change is always pointed in three matters, namely the price of crude oil, the IDR exchange rate and the volume of consumption. There is inevitably problem with the amount of subsidies. When the price of oil rises, the value of the exchange rate falls, and the volume of consumption rises, then the subsidy spending will swell, thus burdening the state budget (APBN). In the end, the Government sacrifices capital expenditure by reducing its budget allocation or accumulating debt to increase the shortage of subsidies.

This subsidy problem arises because of the consequences of government policies that provide price subsidies to the public. For certain fuels, such as premium, diesel, kerosene, and $3 \mathrm{~kg}$ LPG, the Government provides subsidies equal to the difference between the benchmark price minus the retail price. In electricity, the Government subsidizes the difference in cost of supply (BPP) plus the margin minus the selling price. Therefore, when crude oil rises the price of fuel which is a product of crude oil will increase. As a result, the benchmark price or BPP will increase and then the subsidy will increase as well. In addition, when the volume of consumption increases, the subsidy will also increase [11]. 
The International Energy Agency (IEA) direction in the KEN (National Energy Policy) determined includes:

1) Availability of energy for national needs

2) Priority for energy development

3) Utilization of national energy resources

4) National energy buffer reserves, as in The National Energy Council, established through Number 26/2008 Presidential Regulation, is given the task:

a. To design and formulate a national energy with the approval of the DPR.

b. To decide National Energy General Plan (RUEN).

c. To strive and deal with energy crisis and emergencies.

d. Overseeing the implementation of policies in the energy sector that is cross sector.

Indonesia is a country with presidential government system, making the control authority of each line of government administration in the hands of the president. The presidential government system does not make DEN's accountability and supervision of national energy policies effective, the clause will only be in vain. Law Number 30/2007 Concerning Energy and PP Number 79 / 2014 Concerning KEN thus gives blank authority to DEN. The legislative reason behind the enactment of regulations on oil and gas energy is questionable when DEN is placed as the institution in charge and supervisory body, without having authority to impose sanctions against infringement of the KEN and RUEN that has been established.

DEN is responsible for the availability of national energy but all control authority remains in the hands of the president, so it is not rational, an institution that does not have the authority to control energy in the sovereign as an institution responsible for the availability of national energy. The provisions regarding DEN as an institution responsible for the availability of national energy, as if similar to the provisions of government "hand washing" in the energy sector, with these articles the government controls all energy affairs but responsibility for the availability of Indonesia national energy left to DEN as the party responsible answer according to the energy law.

The Constitutional Court interprets the word "control" owned by the Indonesian government as stated in Article 33 of the 1945 Indonesia Republic Constitution in the Constitutional Court decision Decree Number 001-021-022 / PUU-I / 2003, which was pronounced in a public hearing on Wednesday, 16 December 2004, stating in essence that the meaning of the word mastery in the state includes, among others, giving the recommendation to the state to hold policies (beleid) and management actions (bestuursdaad), regulation (regelendaad), management (beheersdaad) and supervision (toezichthoudensdaad) for purposes of -the magnitude of people's prosperity, as in [5].

\section{CONCLUSION}

Legislation is a guideline and reference, so the legislation must be consistent, synchronous, coherent, and harmonious with other laws and regulations. Legislation that does not meet the consistent, synchronous, coherent, and harmonious nature will lose its validity value as a guideline so that it cannot be used as a reference, if it happens on its own, the laws and regulations will become can't implement and ineffective.

Indonesia has no choice, the oil and gas energy sector is a strategic field, to improve the energy sector Indonesia needs to improve the construction of legal arrangements so that it is more rational. These improvements are to improve Law Number 30 /2007 Concerning Energy and Rules Number 79 / 2014 Regarding KEN which is ambiguous, returning the authority regulated by institutional arrangements adjust to legal reasons approved by government laws and regulations approved regulations should be. First, returning the authority to the president and the ministry because the control authority is centralized to the president and presidential aides, namely the ministry as the government system adopted in Indonesia, namely the presidential system.

Second, Indonesia needs to have a legal construction of legal judicial review under the Law with a legal construction that is more able to filter violations of ambiguity in the legislation. The construction of legal judicial review under the law with legal construction that is able to capture violations committed by the government when a regulation turns out to violate the principles of drafting legislation as regulated in Law Number 12 of 2011 concerning the Legislative Drafting. Construction of legal judicial review under the law with realistic legal construction so that Indonesia does not become a wilderness of legislation that is poor in harmony and poor in synchronization. Third, erase the existence of DEN by returning the main tasks and functions to Energy and Mineral Resources Minister.

\section{REFERENCES}

[1] P. Gandhi, "Analisis Kualitatif Nilai Ekspor Migas Indonesia dan Kepemilikan Blok Migas oleh Perusahaan Asing di Indonesia," Jurnal Ekonomi Pertanian, Sumberdaya dan Lingkungan, vol. 1, no. 1, pp. 87-101, 2014.

[2] J. Hage, "social science research network," 9 February 2011. [Online]. Available:

https://papers.ssrn.com/sol3/papers.cfm?abstract_id=1599531\#. [Accessed 15 October 2019].

[3] B. Lubiantara, "Dinamika Industri Migas: Catatan Analis OPEC," Petromindo.com, Jakarta, 2015.

[4] P. M. Marzuki, Penelitian Hukum, Jakarta: Kencana Prenadamedia, 2005.

[5] I. Cahyani, "Prinsip Keterbukaan dalam Pengelolaan Hulu MIgas di Indonesia (Disertasi)," Fakultas Hukum Universitas Airlangga, Surabaya, 2019.

[6] E. P. Widiati, "Efficient Public Participation in the Local Law Making Process," Yuridika, vol. 33, no. 3, 2018.

[7] M. U. M. Putera and S. Damanik, "Pengaruh Ekspor Migas dan Non Migas Terhadap Posisi Cadangan Devisa di Indonesia," Jurnal Wira Ekonomi Mikroskil, vol. 7, no. 2, pp. 243-253, 2017.

[8] Mukhtasor, Pengantar Ilmu Lingkungan, Surabaya: ITS Press, 2008.

[9] A. R. M. Umar, "Analisis Kebijakan Liberalisasi Sektor Hulu Migas Indonesia pasca-1998," Jurnal Ilmu Sosial dan Ilmu Politik, vol. 16, no. 1, pp. 45-61, 2012. 
[10] R. Hague and M. Harrop, Comparative Government and Politics; An Introduction, New York: Palgrave, 2004.

[11] M. Nasir, "Potret Kinerja Migas Indonesia," Buletin Info Resiko (IRF), Jakarta, 2014. 